\title{
Inclusive virtuous circles
}

Citation for published version (APA):

Gassmann, F. (2018). Inclusive virtuous circles: Why governments need to invest in social protection (and why it's in their own best interests)". Maastricht University. https://doi.org/10.26481/spe.20180323fg

Document status and date:

Published: 23/03/2018

DOI:

$10.26481 / \mathrm{spe} .20180323 \mathrm{fg}$

Document Version:

Publisher's PDF, also known as Version of record

\section{Please check the document version of this publication:}

- A submitted manuscript is the version of the article upon submission and before peer-review. There can be important differences between the submitted version and the official published version of record.

People interested in the research are advised to contact the author for the final version of the publication, or visit the DOI to the publisher's website.

- The final author version and the galley proof are versions of the publication after peer review.

- The final published version features the final layout of the paper including the volume, issue and page numbers.

Link to publication

\footnotetext{
General rights rights.

- You may freely distribute the URL identifying the publication in the public portal. please follow below link for the End User Agreement:

www.umlib.nl/taverne-license

Take down policy

If you believe that this document breaches copyright please contact us at:

repository@maastrichtuniversity.nl

providing details and we will investigate your claim.
}

Copyright and moral rights for the publications made accessible in the public portal are retained by the authors and/or other copyright owners and it is a condition of accessing publications that users recognise and abide by the legal requirements associated with these

- Users may download and print one copy of any publication from the public portal for the purpose of private study or research.

- You may not further distribute the material or use it for any profit-making activity or commercial gain

If the publication is distributed under the terms of Article $25 \mathrm{fa}$ of the Dutch Copyright Act, indicated by the "Taverne" license above, 
Prof.dr. Franziska Gassmann

Faculty of Humanities and Sciences

Inclusive virtuous circles:

Why governments need to invest in social protection (and why it's in their best interest) 


\section{Inclusive virtuous circles:}

\section{Why governments need to invest in social protection (and why it's in their best interest)}

\section{Franziska Gassmann Inaugural Lecture, 23 March 2018}

"There does not have to be trade-off between growth and social protection. A democracy does not mean much if it doesn't respond to the needs and will of its people."

(Michelle Bachelet, former President of Chile)

Mevrouw de Rector, Mijnheer de Decaan, hooggeleerde collega's,

Liebe Freunde und Familie,

Dear colleagues and students, ladies and gentlemen,

The world has come a long way since the early 1990s and the establishment of the Millennium Development Goals. Poverty reduction is considered a success story. More than one billion people have escaped extreme poverty and other human development indicators have also improved remarkably. It seems we are living in a much better world today than two decades ago. Yet, a staggering 700 million people are still extremely poor, which is about 10 percent of the world's population (World Bank, 2018). More than half of them are living in a country in Sub-Saharan Africa. Moreover, those that have been left behind have not seen an improvement in their living conditions. The average distance of the poor to the poverty line remained almost unchanged (Ravallion, 2016).

What does it mean to be poor? It is not simply a matter of having little money. It means not being able to participate in society; to forego treatment in case of sickness; not being able to give the children a better future; not having clean water or safe housing; it means to be stuck in a vicious circle because in order to improve one's livelihood, money is needed to buy assets or find a job. In every aspect, the poor have fewer options to deal with risks and shocks. Some of the consequences of a life in poverty are constant food insecurity, lower educational achievements, a lower health status, lower life expectancy, and a high vulnerability towards economic and natural shocks. These are all factors that affect our productivity, which is a key determinant of a country's economic potential (Szirmai, 2015). 
Children are particularly at risk of living in poverty. Every fifth child in the developing world is extremely poor. Globally, children account for more than half of the extreme poor (UNICEF and World Bank, 2016). Hence, it is no surprise that in 2016155 million children under the age of five showed signs of chronic malnutrition. This is 23 percent of all children of this age group (UN, 2017). Child poverty and malnutrition have devastating consequences in the long term not only for the children themselves, but also for the societies, they live in. We know from research that deprivation in childhood (particularly early childhood) causes irreparable damages in the physical, emotional and cognitive development of individuals (DFID et al., 2012; Samson, Fajth and François, 2016). Childhood is a unique window of opportunity to make long lasting investments (Heckman, 2008). Children have specific (basic) needs, and failure to meet them jeopardizes their development and deprives them in their capabilities (Sen, 1999). Poor children are also very likely to become poor adults. Estimations based on data from Eurostat suggest that in countries like Croatia, Hungary or Bulgaria, which are not too far from here, more than 90 percent of poor adults were also deprived during childhood (Grundiza and Lopez Vilaplana, 2013).

In September 2015, the global community pledged to eradicate extreme poverty and hunger by 2030 . How likely is it that we will achieve this objective? Economic growth alone will not do the trick as various forecasts have shown (World Bank, 2016; Bluhm et al., 2015). Only if the poor benefit proportionally more from economic growth than the rich do, we might achieve the goal. Hence, the redistribution of income and wealth has to be part of the game. Or in the words of Jim Yong Kim, president of the World Bank: "We need to find an economic growth model that's inclusive, that lifts up the poorest citizens rather than maintains those at the top" (World Bank, 2015a).

If the first Sustainable Development Goal ("End poverty in all its form everywhere") is to be taken seriously, most low and middle-income countries have a considerable challenge ahead. It will require substantial efforts at global and national levels. It requires policies that address chronic poverty traps and improve the lives of poor and vulnerable populations. Social protection policies can play a decisive role in this endeavor, and that is what I would like to talk about in the remainder of this lecture.

Some of you may wonder what I am exactly referring to. What is social protection? Most of you have or will benefit from social protection policies over the course of your lives. Depending on the country where you were born, your mother has been granted paid pregnancy leave; your parents may have received a birth grant and enjoyed regular family benefits until you reached adulthood. During your working life, some of you got ill, had a work accident, or even lost the job. If that happened in Europe, you were covered by national social insurance schemes. These shocks did not endanger your ability to make ends meet because you were protected by the system. It gave you time to get better or to find another job. Even in the worst case, when all income sources are exhausted, the state offers us protection. We can apply for income support. These safety nets guarantee a minimum income such that our basic needs are covered. For us, living and working in Europe, this is normal. We take it for granted. Yet, globally, only 45 percent of the population enjoys some kind of social protection. Four billion are completely unprotected (ILO, 2017).

There is no single definition of social protection, yet all encompass the provision of public programs for the prevention, reduction and elimination of economic and social vulnerabilities to poverty and 
deprivation. Typical components are social insurance policies, social assistance or safety net programs and social services. While entitlements to social insurance depend on previous employment records, the eligibility for social assistance does not depend on any contributions made in the past. That is why we also refer to them as non-contributory social protection. These programs are financed from government resources and are intended to support consumption and access to social services. Cash transfers are essential components of any well-developed social protection system. Near-cash, in-kind, nutrition and health interventions can also provide valuable support to households. Social services and programs to ensure access to services, such as education or health, further promote the capacity of households. In my work, I am particularly interested in the potential of social assistance policies given that in developing countries the share of people covered by social insurance programs is still small.

In this inaugural lecture, I would like to address three related questions: what is the role of social protection for poverty reduction? Why should governments invest in social protection? And last but not least, is there an ideal policy model?

\section{What is the role of social protection?}

In Europe, social protection policies have a long history. They played a major role in the reduction of inequality until the mid-1980s (Atkinson, 2013), and they remain important for poverty reduction. In 2016, social transfers reduced poverty in the European Union by one third from 26 to 17 percent (Eurostat, 2018a; 2018b). In Finland, Denmark and Norway, countries that are well known for their comprehensive welfare states, social transfers reduced poverty rates by half. You may now think that these countries are very rich and that poverty is hardly an issue. Yet, the share of the population at risk of poverty before transfers is about the same in Finland or Denmark as in Bulgaria or Greece. What matters is the fact that the social protection systems in countries like Finland or Denmark support almost all people living in jobless or poor households (Maquet et al., 2016). The direct reduction of poverty is not the only positive outcome. Because our social protection systems are largely financed through taxes and contributions, they redistribute income and wealth. Although both transfers and taxes contribute to the reduction of inequality, in high-income countries social protection transfers alone account for three-quarter of the reduction (OECD, 2012).

Europe also shows us what social protection means for child poverty. Just to give you two examples: In Ireland, social transfers reduced the incidence of child poverty by two thirds, from 45 percent to just above 15 percent and in Bulgaria, transfers were responsible for a 25 percent lower incidence of child poverty (ILO, 2015). The correlation between child poverty reduction and social spending on families and children is strong. Higher expenditures are associated with larger reductions in child poverty (Bradshaw and Hirose, 2016).

Even though social protection policies play an important role in the European Union, our welfare states are under constant pressure and subject to reforms. During the last economic crisis, many countries took austerity measures thereby reducing the budget available for social protection - and that at a time when it was most needed (Ortiz et al., 2015). Last-resort social protection schemes, such as the minimum income guarantee programs, have also undergone major reforms in many countries. In the Netherlands, for 
example, social assistance receipt became increasingly conditional. The state mandates a certain behavior of beneficiaries, which attests to the presumption that welfare recipients are by definition passive. They need to be activated. Yet, most beneficiaries are looking only for one thing: to find work so that they no longer depend on the state (Bierbaum and Gassmann, 2016).

The increase of non-standard contracts and self-employment in many European countries presents another challenge to our welfare states. Our social insurance systems have been designed with a standard worker in mind. Due to the nature of this - sometimes precarious - type of employment, these workers might not contribute to social insurance. Their future pension entitlements might be severely limited due to career interruptions, irregular incomes, or low earnings. This means that those most vulnerable in the labor market are less protected against lifecycle risks. Even though they have statutory access to social insurance, they might not be able to meet the eligibility criteria to receive benefits, because of insufficient contributions made in the past (Spasova et al. 2017). Their situation is similar to workers in the informal sector in developing countries, which are also not part of formal social insurance schemes.

In low- and middle-income countries, social protection is even more important, but also more contested. The share of the population that is poor or living in vulnerable conditions is high. The exposure to shocks, be it economic, social, political or climate-related, is considerably higher. Yet, governments are reluctant to invest in social protection policies.

The right to social protection has been progressively recognized and realized around the world over the last century. Social protection and a decent standard of living are human rights. They are entrenched in international agreements such as the United Nations' Universal Declaration of Human Rights (United Nations 1948), the International Covenant on Economic, Social and Cultural Rights (United Nations 1966), and the Convention on the Rights of the Child (United Nations 1989). The potential of social protection systems for the eradication of poverty also features prominently in the Sustainable Development Goals. Target 1.3 requires countries to "Implement nationally appropriate social protection systems and measures for all, including floors, and by 2030 achieve substantial coverage of the poor and the vulnerable" (UN, 2015). Social protection is also expected to play a role in achieving other SDGs, such as SDG number 5 (Achieving gender equality and empowerment for women and girls) and SDG number 10 (Reduce inequality within and among countries).

Over the last decade or two, an overwhelming body of evidence has been established that confirms the positive effects of social protection in low and middle income countries (for example, Handa and Davis, 2006; Barrientos and Scott, 2008; ILO, 2010; Arnold et al., 2011; IEG, 2011; Tirivayi et al., 2013; World Bank, 2015b; Bastagli et al., 2016). Social assistance, in particular cash transfers play an important role in guaranteeing a minimum consumption level for poor and vulnerable households. They enable productive livelihoods and promote the access and utilization of other public services, such as education or health care. Cash transfers have proven to be effective tools to reduce poverty and inequality, increase human and physical capital, generate local and regional multiplier effects and foster economic and social mobility. It is widely acknowledged that social protection policies strengthen the resilience of households against economic, social and climate shocks. They support economic growth and productivity and act as social stabiliser. 
Despite the overwhelming positive evidence of social protection, many governments in low and middleincome countries remain reluctant towards the idea. Yes, almost all countries in the world offer at least one type of social support (World Bank, 2017). Yes, the number of countries with cash transfer programs for the poor has increased considerably over the last 10 years. Yet, these programs are often small, not anchored in national legislation or operate only on a pilot basis.

The policy makers' hesitation to fully embrace social protection is basically guided by three preconceptions: first, there are the populist arguments that the poor do not deserve public support because it is their own fault that they are in this position. They are lazy and if we give them money, they have no incentive to participate in the labor market and earn their own income. Emily Badger and Margot Sander-Katz succinctly explained in a recent article in the New York Times (The Upshot, 3 February 2018) how, after 400 years, we still distinguish between the deserving and undeserving poor, or the idle versus the industrious, the able-bodied versus the old and sick. It is also an argument that I have heard repeatedly from government officials. In our own research we have shown that cash transfers have no negative effect on labor market participation in former communist countries (Gassmann and Trindade, 2016; Gassmann et al., 2016a). Other authors came to similar conclusions for other countries (Banerjee et al., 2017).

The second preconception stems from fiscal considerations. Governments in low-income countries claim that they cannot afford social protection, that the group in need of support is simply too large. The ILO has convincingly shown that fiscal space can always be found if there is political will (Pal et al., 2005; Ortiz, et al., 2017a, 2017b). Finally, the third preconception is that public spending for social protection is a cost, and not an investment. This brings me to the core argument of this speech.

\section{Why should governments invest in social protection?}

Governments have good reasons to invest in social protection. We can make several arguments. The first relates to the changing demographic context, which also played a role in the emergence of European welfare states. The industrial revolution changed work and living arrangements and demographic changes led to the rise of nuclear families. The elderly and disabled were no longer cared for within families, and workers needed protection in case of sickness or age, when they would no longer be able to work. According to the theory of the welfare pentagon, developed by my former colleague, Professor Chris de Neubourg, households have in principle five channels to manage risks and cope with the effects of a shock: within the household itself, through markets, social networks or membership organizations, or via state support (de Neubourg, 2002). Yet, not all these channels may be available or effective. Traditional informal safety nets are on the decline. In the context of urbanization and globalization, family members migrate to cities or even abroad, often leaving the elderly and children behind. In the best case, they manage to improve their situation and support the family financially. However, adult children might be too poor to help their parents. This was for example a common phenomenon during the economic transition in Eastern Europe and Central Asia. Elderly parents had to support their adult children, which was, by the way, possible thanks to the remaining pension systems, which guaranteed a low but regular income (Gassmann, 2000). Another example comes from contemporary Mongolia, where rural households send informal transfers to family members that migrated to the capital city, and not the other way around as one would expect. 
Two key arguments stem from public economics. First, markets may fail to provide adequate insurance against the impacts of various risks. In low-income countries, the risks and related costs are often aggravated and private insurance markets are missing or very thin. Second, an individual's failure to manage risks can impose costs on others in the society. Think, for example, of communicable diseases that are untreated due to lack of health insurance or financial means. If large groups remain uninsured, the social costs may be high.

In my view, the most powerful argument for investments in social protection relates to economic growth. Economic growth, although essential for a country's development, does not necessarily lead to substantial poverty reduction. About ten years ago, a new paradigm entered the development debate: inclusive growth. Inclusive growth creates opportunities for all in a society and ensures that everybody benefits from increased prosperity (OECD, 2014). And that, eventually, will strengthen economic growth.

My dear colleague Professor Adam Szirmai has devoted most of his life to the study of economic development. His focus is on the macro-economic side, yet his theories are extremely useful to make my case and make the link to the micro economy, or in other words, the people living in this economy. According to Adam Szirmai, economic growth derives from proximate, intermediate and ultimate factors (Szirmai, 2012). Examples for proximate factors are technological change, capital accumulation, and labor productivity. Aggregate demand, national policies, or a change in the terms of trade are intermediate factors; examples for ultimate sources of growth are geographic conditions, demographic trends, or social attitudes and power relations. Social protection is linked to economic growth through different transmission channels at household, community and national level. Social protection enables households to invest in human capital and livelihoods. It acts as a stabilizer of internal demand, particularly at the community level; and, it fosters social cohesion and inclusion. Armando Barrientos refers in this context to growth-mediating processes. Social transfers have the potential to remove credit and liquidity constraints, protect assets and consumption and enable poor households to better allocate their resources (Barrientos, 2012). Hence, the role of social protection for inclusive growth and development is manifold: it redistributes income to the poor and vulnerable; it enables households to make better investments; and, it helps households to manage risks. Social protection contributes to economic growth in its traditional definition - by increasing a country's output - but it also makes growth inclusive by enabling the poor and vulnerable to participate and benefit from economic growth.

During the last five years, I have dedicated a lot of my time to empirically prove this argument. If we can show that investments in social protection generate positive returns - or, in the words of the title: induce a virtuous circle - we will have a powerful argument in favor of allocating resources to social protection, even in poor countries. Together with my colleagues, we have established a conceptual framework and developed a methodology to calculate ex-ante the expected rates of return of investing in social protection. So far, we have applied our method to countries as diverse as Cambodia, Lesotho and Uganda (Mideros et al., 2016; Dietrich et al., 2016, 2017a, 2017b). This year we have started a similar project in Kenya. Our analyses show that in the long term the benefits of providing cash transfers to poor and vulnerable households exceed the costs. This is good news and bad news. The good news is that the returns are eventually positive. The bad news: it takes time. Why bad? The decision whether or not to 
invest in social protection relies with politicians that are often myopic. Standing in for policies that will only 'pay back' after several government cycles takes foresight and political courage.

This brings me to some other questions: to what extent does policy design matter, and what explains that some of the poorest countries in the world fully embraced social protection and invested a substantial part of their budgets?

\section{Is there an ideal model?}

Let us assume a government is convinced about the virtue of providing social protection to poor and vulnerable households and individuals. What form should it take? Should support be provided in cash or in kind? Should benefit receipt be tied to certain conditions? Should the whole population benefit or only specific groups? It may be evident that there are no blueprints. Every country is different with different needs and resources. Yet these key design issues are often debated as if there is a one-size-fits-all policy model. Moreover, the debate is at times polemic, guided by ideology rather than evidence or consideration of a country's situation.

The question, whether social protection is more effective if provided in cash or in kind is probably the least contested. Except for specific circumstances, for example in the case of acute market shortages, cash is the preferred option. Beneficiaries have the freedom to spend the money according to their preferences, and providing cash is administratively less expensive. Evidence shows that the poor spend the cash wisely. Satisfying the basic needs of the family members has the first priority. Households use the money to increase food consumption, pay for the children's education or spend it on health care (Evans and Popova, 2014). Moreover, these programs also benefit the wider community. The money is spent locally, thereby increasing the demand for goods and services. Evidence from several countries in Sub-Saharan Africa shows that a dollar invested in a poor household multiplies total community income between 1.3 and 2.5 times on average (Taylor et al., 2016). More recently, the trend is towards combining cash with the provision of additional goods and services. These 'cash plus' programs, as for example implemented in Ethiopia, Ghana or Chile show promising results regarding the sustainable reduction of poverty (Roelen et al., 2017).

The question whether benefit receipt should be tied to specific conditions is more contested. The origin

of conditional cash transfers was in Latin America. They became increasingly popular in the late nineties and early zeros. Currently, 67 developing countries have a conditional cash transfer program (World Bank, 2017). Conditionality asks for some form of behavioral compliance in the exchange for money or goods. In order to continue receiving support, beneficiaries have to meet certain conditions that are spelled out by the program (Schüring, 2010). Typical conditions are regular school attendance or health checks. Engaging in public work or participation requirements as in the Netherlands, are, strictly speaking, other examples of conditionality, although they are not referred to as such. The underlying idea of a conditionality is to change the behavior of the poor, which is assumed to cause their perpetual poverty and vulnerability. Following a purely economic rationale, conditional cash transfers are inefficient if a household is constrained in the allocation of its budget (Schüring, 2010). The proponents of conditional cash transfers argue that they increase the investments in human capital, particularly of children, leading to increased 
school enrolment and better nutritional outcomes. The opponents claim that conditions are inefficient. They impose an additional burden on the poor and punish those that cannot comply with the conditionality for various reasons. The evidence on the effectiveness of conditional cash transfers is mixed (Baird, et al., 2014; Bastagli et al., 2016). There have only been few impact evaluations that allowed analyzing the difference. Hence, it is almost impossible to say whether the observed effects are due to the additional cash in the household or the condition.

Maybe the most fiercely debated issue is the question, who should benefit from social protection. Should anti-poverty programs be targeted to the poor or should access be universal? It is a longstanding debate, where the proponents and opponents of targeting seem to have dug in their heels. From a theoretical perspective, with a given budget, targeting anti-poverty programs to the poor is the most efficient and effective option to reduce poverty (Atkinson, 1995). Yet, "people ... underestimate how difficult it is to target the poor" (van de Walle, 1998:232). Efforts to decrease leakage to the non-poor can lead to increasing exclusion errors, because the ever-stricter application of targeting rules may exclude some of the targeted population (Cornia and Stewart, 1993). The optimal policy is not necessarily a policy that targets benefits as narrowly as possible (Sen, 1995; Moehne and Wallerstein, 2001; Gelbach and Pritchett). Strongly residual welfare states are unsustainable in the absence of altruistic voters. Yet, as our study in Zambia has shown, "the relationship between political considerations and targeting may be less straightforward than thought" (Schüring and Gassmann, 2016:825). Other factors, such as attitudes towards the poor, understanding of the concept of social justice, perceptions about the fairness and effectiveness of social assistance programs and program experience influence targeting preferences.

At the global level, there is a strong movement towards universal social protection. The ILO Recommendation 202, adopted in 2012, commits countries to extend minimum income guarantees and access to essential health care to all its citizens. Several countries in Europe (and beyond) pilot or discuss the introduction of a universal basic income. But the discussion is not confined to high-income countries. In India, for example, the Ministry of Finance is considering a basic income to replace the current social protection programs (Government of India, 2017). Even if the universal provision of social protection is the ultimate goal, the question remains to what extent this is feasible. Societies have different preferences for redistribution as evidenced by the different welfare state models in Europe and throughout the world.

Why have countries, including some of the poorest in the world, decided to invest in social protection? Why are other countries lagging behind despite the overwhelming international evidence? What are the main factors behind investments in social protection? Our own research tells us that countries with functioning government institutions and with societies in favor of redistribution are more likely to invest in social protection (Gassmann et al. 2016b). While the international community plays an important role in creating global awareness about social protection, their influence at the national level is often limited, unless there is clear leadership and trust among partners (Cherrier, 2016).

\section{Relevance of topic and future research}

Social protection policies, particularly the non-contributory schemes play an important role in guaranteeing a minimum consumption level for poor and vulnerable households in developing countries. 
They enable productive livelihoods and promote the access and utilization of other social services. Even though most countries provide some form of social protection, the gaps in coverage of the poor and vulnerable remain substantial (ILO, 2017; World Bank, 2017). Moreover, the level of support is often insufficient to have a meaningful impact on poverty. In most low and middle-income countries, antipoverty programs suffer from large exclusion errors and insufficient transfers. Given limited fiscal resources, governments are faced with the dilemma whether to extend the horizontal (coverage) or the vertical dimension (adequacy) of social protection (Gassmann, forthcoming; Gassmann and Notten, 2008).

We need to further our knowledge of the social, economic and political factors influencing the introduction and extension of social protection systems in low- and middle-income countries. In the coming years, I want to focus not only on better understanding which mechanisms and instruments are effective and costefficient given a specific economic and social environment, but also critically assess the potential longterm effects of public and private social protection investments. Our research will help understand how social protection affects intermediate objectives such as the accumulation of human capital, the investment in productive assets, labor market participation and the conditions under which social protection contributes to inclusive growth.

We have plenty of evidence that social protection is effective in increasing the resilience of households against shocks. Yet, we do not know under what conditions social protection systems are sustainable given the global challenges, such as increasing inequality within and across countries, or the risks associated with climate change, migration and humanitarian crises. Some of the questions I would like to address refer to the conditions under which social protection can play a role in the sustainable graduation from poverty, the reduction of inequality and the promotion of economic and social mobility. To what extent do preferences for redistribution matter? Current evidence mainly focuses on the positive effects of social protection, yet the unintended consequences are hardly investigated. This also raises the question whether social protection policies are indeed the most effective and efficient instruments to achieve the SDGs. Where are the limits to what social protection can achieve?

There is a strong demand for rigorous public policy analysis to inform policy decisions at all levels thereby contribution to the transparency and accountability of policy stakeholders. We will continue to engage with national governments, bilateral donor agencies and international organizations and contribute to the public debate at national and international level. As researchers and teachers, we have quite a privileged life, but we also serve the greater good. Hence, we should use our knowledge and skills to contribute to better policies, and as teachers, train the next generation of policy makers.

\section{Words of thanks}

Before I come to the end of this speech, I would like to take time for some personal comments and words of thanks. Life is hardly ever a straight line. That I am standing here today is basically the result of love and luck. As most of you know, I was born and raised in Switzerland. At the age of 20, I had rather different dreams of what I wanted to become. Professor was not one of them. To the despair of my father, I even decided against university, but started a career in the fashion industry. Love then brought me to the Netherlands, where I started from scratch. I studied economics here in Maastricht, and I was lucky. Lucky 
to meet Chris de Neubourg. Towards the end of my study, he invited me to join a big World Bank project in Latvia and Lithuania, and that was the beginning of my career in poverty, public policy analysis and social protection. The project in Latvia also gave me the opportunity to write my dissertation. I had a part-time contract at SBE, where I combined teaching with the project work and my research. Chris also convinced me to come back to Maastricht after a few years and help building the School of Governance. Chris - thank you for everything, but most of all for your continued encouragement and friendship.

Many other persons have been decisive for my career. I would not be standing here today and give my inaugural lecture without the support of Rianne Letschert, our rector magnificus, Bernadette Jansma, our former dean, and Bart Verspagen, director of UNU-MERIT and my boss. You encouraged me and supported my application. Thank you. I would also like to thank the other members of the review committee, in particular Armando Barrientos from the University of Manchester, one of the most eminent scholars in social protection. Thank you for giving me the opportunity to spend a few months in Manchester.

My home is the Maastricht Graduate School of Governance and UNU-MERIT. It is the ideal environment to study social protection and development. I benefit immensely from my colleagues with their different interests and expertise. You broaden my horizon and enrich my research. I truly enjoy working together with the PhD students. Thank you for your patience, but also thank you for the new ideas you bring. During the years that I was a self-employed consultant, I realized how important it is for me to work in a team, to have colleagues, to have a work home, so to speak. You, my dear colleagues, make it a place I like going to every day. Thanks for the many moments of happiness and joy, and, of course, the morning coffee.

None of this would have been possible without the support of family and friends. Thank you for joining me on this day in Maastricht and celebrate with me. Willem, I cannot tell you how grateful I am to have you at my side. You are my beacon, my solid rock. You are the most generous person I know. As part of my work, I am traveling the world. I am gone regularly for one, two weeks. You never complain. To the contrary: you always encourage me. If every woman would have such a supporting husband, gender equality would not be an issue.

Last but not least, allow me to address my parents in my mother tongue. Ich weiss, dass ihr gerne hier wärt. Danke, dass ihr mich in allem immer unterstützt habt, auch wenn meine Entscheidungen vielleicht nicht immer in ganz nach eurem Sinn waren. Diese Rede, dieser Moment, ist euch gewidmet.

Ik heb gezegd. 


\section{References}

Arnold, C., Conway, T. and M. Greenslade (2011). Cash transfers. London: DFID Department for International Development.

Atkinson, A.B. (1995). On Targeting Social Security: Theory and Western Experience with Family Benefits. In: van de Walle, D. and K. Nead (eds.). Public Spending and the Poor: Theory and Evidence. Baltimore and London: The Johns Hopkins University Press.

Atkinson, A.B. (2013). Reducing Income Inequality in Europe. IZA Journal of European Labor Studies, 2013, 2-12.

Badger, E., and M. Sanger-Katz (2018). Who's Able-Bodied Anyway? The 400-year history of how we talk about the deserving versus the undeserving poor. The Upshot, The New York Times, 3 February 2018.

Baird, S., Ferreira, F.H.G., Özler, B. and M. Woolcock (2014). Conditional, unconditional and everything in between: a systematic review of the effects of cash transfer programmes on schooling outcomes. Journal of Development Effectiveness, 6(1), 1-43.

Banerjee, A.V., R. Hanna, G.E. Kreindler and B.A. Olken (2017). Debunking the Stereotype of the Lazy Welfare Recipient: Evidence from Cash Transfer Programs. The World Bank Research Observer., 32(1), 155-184.

Bastagli, F., Hagen-Zanker, J., Harman, L., Barca, V., Sturge, G., Schmidt, T. \& Pellerano, L. (2016). Cash transfers: what does the evidence say? A rigorous review of programme impact and the role of design and implementation features. London: Overseas Development Institute.

Barrientos, A. (2012). Social Transfers and Growth: What Do We Know? What Do We Need to Find Out?. World Development, 40(1), 11-20.

Barrientos, A. and J. Scott (2008). Social Transfers and Growth: A Review. Brooks World Poverty Institute Working Paper, No. 52. Manchester: Brooks World Poverty Institute.

Bierbaum, M. and F. Gassmann (2016). Limits of Freedom? Experiences with the Participation Act. UNU-MERIT Policy Brief, 2016(2) (English version). Maastricht: UNU-MERIT.

Bluhm, R., de Crombrugghe, D. and A. Szirmai (2015). Poor Trends: The Pace of Poverty Reduction after the Millennium Development Agenda. in: L. Haddad, H. Kato and N. Meisel (eds.). Growth is Dead. Long Live Growth. The Quality of Economic Growth and Why it Matters. Tokyo: AFD, IDS and JICA.

Bradshaw, J. and K. Hirose (2016). Child benefits in Central and Eastern Europe. A comparative review. Geneva: International Labour Organization.

Cherrier, C. (2016). The Expansion of Basic Social Protection in Low-income Countries. PhD dissertation Maastricht: Maastricht University and United Nations University.

Cornia, G.A. and F. Stewart (1993). Two errors of targeting. Journal of International Development, 5(5), 459-496.

de Neubourg, C. R. J. (2002). The Welfare Pentagon and the Social Management of Risks. In Sigg, R. and C. Behrendt (eds.), Social Security in the Global Village. New Brunswick: Transaction Publishers.

DFID UK, HelpAge International, Hope \& Homes for Children, IDS, ILO, ODI, Save the Children UK, UNICEF, UNDP and The World Bank (2009). Joint statement on advancing child-sensitive social protection. New York: UNICEF. 
Dietrich, S., Gassmann, F., Röth, H., \& N. Tirivayi. (2016). Estimation of Rates of Return (RoR) on Social Protection Investments in Lesotho. Maastricht: Maastricht Graduate School of Governance.

Dietrich, S., Malerba, D., Barrientos A. and F. Gassmann (2017a), Rates of return to antipoverty transfers in Uganda, UNU-MERIT Working Paper, 2017-040. Maastricht: UNU-MERIT.

Dietrich, S., Malerba, D., Barrientos, A., Gassmann,F., Mohnen,P., Tirivayi,N., Kavuma, S. and F. Matovu (2017b), Social protection investments, human capital, and income growth: Simulating the returns to social cash transfers in Uganda, UNU-MERIT Working Paper, 2017-029. Maastricht: UNU-MERIT.

EUROSTAT (2018a). People at risk of poverty before social transfers. Eurostat online data code (t202052).

EUROSTAT (2018b). People at risk of poverty after social transfers. Eurostat online data code (tesov250).

Evans, D. and A. Popova (2014). Cash Transfers and Temptation Goods: A Review of Global Evidence. World Bank Policy Research Working Paper, 6886. Washington DC: The World Bank.

Gassmann, F. (2000). On the Verge of Poverty. Welfare and Economic Transition in Latvia. Maastricht: Universitaire Pers.

Gassmann, F. (forthcoming). The Potential Contribution of Non-contributory Social Assistance Schemes (Cash Benefit Schemes) and Universal Schemes to the Closure of the Protection Gap in Asia. In: Cichon, M., and S. Handayani (eds). Assessing the fiscal resource requirements for adherence to the social protection agenda of the Sustainable Development Goals (SDGs) in Asia. Manila: Asian Development Bank.

Gassmann, F., and G. Notten (2008). Size Matters: Poverty reduction effects of means-tested and universal child benefits in Russia. Journal of European Social Policy, 18(3), 260-274.

Gassmann, F., and L.Z. Trindade (2016). The effect of means-tested social transfers on labour supply: heads versus spouses - An empirical analysis of work disincentives in the Kyrgyz Republic. UNU-MERIT Working Paper, 2016-030 Maastricht: UNU-MERIT.

Gassmann, F., François, D., and L.Z. Trindade (2016a). Social welfare benefits and their impacts on labour market participation among men and women in Mongolia. UNU-MERIT Working Paper, 2016-033. Maastricht: UNU-MERIT.

Gassmann, F., Mohnen, P., and V. Vinci (2016b). Institutional factors and people's preferences in social protection. UNU-MERIT Working Paper, 2016-003. Maastricht: UNU-MERIT.

Gelbach, J. B., and L. Pritchett (2002). Is more for the poor less for the poor? The politics of means-tested targeting. Topics in Economic Analysis and Policy, 2(1), 1-28.

Government of India (2017). Universal Basic Income: A Conversation With and Within the Mahatma. Economic Survey 2016-17, Chapter 9. New Delhi: Ministry of Finance, Department of Economic Affairs.

Grundiza, S. and C. Lopez Vilaplana (2013). Is the likelihood of poverty inherited? Statistics in Focus, $27 / 2013$. Brussel: Eurostat.

Handa, S., and B. Davis (2006). The Experience of Conditional Cash Transfers in Latin America. Development Policy Review, 24(5), 513-536.

Heckman, J. (2008). Schools, skills and synapses. Economic Inquiry, 46(3), 289-324. 
IEG (Independent Evaluation Group) (2011). Evidence and Lessons Learned from Impact Evaluations on Social Safety Nets. Washington DC: World Bank.

ILO. (2010). Effects of non-contributory social transfers in developing countries. A Compendium. Geneva: International Labour Organisation.

ILO (2015). Social protection for children: Key policy trends and statistics. Social Protection Policy Paper, No. 14. Geneva: International Labour Organisation.

ILO (2017). World Social Protection Report 2017. Geneva: International Labour Organisation.

Maquet, I., Maestri, V. and C. Thévenot (2016). The coverage rate of income support measures in the EU: measurement and challenges. Working Paper, 2/2016. Luxemburg: Publications Office of the European Union.

Mideros, A., Gassmann, F., \& Mohnen, P. (2016). Estimation of rates of return on social protection: ex ante microsimulation of social transfers in Cambodia. Journal of Development Effectiveness, 8(1), 67-86.

Moene, K. O., \& Wallerstein, M. (2001). Targeting and political support for welfare spending. Economics of Governance, 2(1), 3-24.

OECD (2012). Economic Policy Reforms 2012: Going for Growth. Paris: OECD Publishing.

OECD (2014). All on Board. Making Inclusive Growth Happen. Paris : OECD Publishing.

Ortiz, I., Cummins, M., Capaldo, J. and K. Karunanethy (2015). The Decade of Adjustment: A Review of Austerity Trends 2010-2020 in 187 Countries. Extension of Social Security Series, No. 53. Geneva: International Labour Organisation.

Ortiz, I., Durán-Valverde, F., Pal, K., Behrendt, C. and A. Acuña-Ulate (2017a). Universal social protection floors: Costing estimates and affordability in 57 lower income countries. ESS Working Paper, 58. Geneva: International Labour Organization.

Ortiz, I., Cummins, M. and K. Karunanethy (2017b). Fiscal space for social protection: Options to expand social investments in 187 countries. ESS Working Paper, 48. Geneva: International Labour Organization.

Pal, K., Behrendt, C., Léger, F., Cichon, M. and K. Hagemejer (2005). Can Low Income Countries Afford Basic Social Protection? First Results of a Modelling Exercise. Issues in Social Protection Discussion Paper, 13. Geneva: International Labour Organization.

Pritchett, L. (2005). A lecture on the political economy of targeted safety nets. Social protection discussion paper series, 0501. Washington: The World Bank.

Ravallion, M. (2016). Are the world's poorest being left behind? Journal of Economic Growth, 21, 139-164.

Roelen, K., Devereux, S., Abdulai, A.G., Martorano, B., Palermo, T. and L.P. Ragno (2017). How to Make 'Cash Plus' Work: Linking Cash Transfers to Services and Sectors. Innocenti Working Paper, 2017-10. Florence: UNICEF Office of Research.

Samson, M., Fajth, G. and D. Francois (2016). Cognitive capital, equity and child-sensitive social protection in Asia and the Pacific. BMJ Global Health 2016, 1(2), 19-27. 
Schüring, E. (2010). Conditions, conditionality, conditionalities, responsibilities - finding common ground. MGSOG Working Paper, 2010WP014. Maastricht: Maastricht University.

Schüring, E. and F. Gassmann (2016). The political economy of targeting - a critical review. Development Policy Review, 34(6), 809-829.

Sen, A. (1999). Development as Freedom. Oxford: Oxford University Press.

Sen, A. (1995). The Political Economy of Targeting. In: van de Walle, D. and K. Nead (eds). Public Spending and the Poor. Baltimore and London: Johns Hopkins University Press.

Spasova S., Bouget D., Ghailani, D. and B. Vanhercke (2017). Access to social protection for people working on nonstandard contracts and as self-employed in Europe. A study of national policies. European Social Policy Network (ESPN). Brussels: European Commission.

Szirmai, A. (2012). Proximate, Intermediate and Ultimate Causality: Theories and Experiences of Growth and Development. UNU-Merit Working Paper Series, 2012-032. Maastricht: UNU-MERIT.

Szirmai, A. (2015). Socio-economic development. $2^{\text {nd }}$ Edition. Cambridge: Cambridge University Press.

Taylor, J.E., Thome, K. and J. Filipski (2016). Local Economy-wide Impact Evaluation of Social Cash Transfer programmes. In: Davis, B., Handa, S., Hypher, N., Winder Rossi, N., Winters, P. and J. Yablonski (eds.). From evidence to action: The story of cash transfers and impact evaluation in sub-Saharan Africa. Oxford, UK: Oxford University Press.

Tirivayi, N., Knowles, M., and B. Davis (2013). The interaction between social protection and agriculture. Rome: FAO UN. (2015). The 2030 Agenda for Sustainable Development. Press release. New York: United Nations.

UN (2017). Progress towards the Sustainable Development Goals. Report of the Secretary-General. New York: United Nations.

UNICEF and World Bank (2016). Ending Extreme Poverty: a Focus on Children. Briefing Note.

Van de Walle, D. (1998). Targeting Revisited. The World Bank Research Observer, 13(2), 231-48.

World Bank (2015a). Governments Should Focus on Shared Prosperity to Address Inequality. Press Release. Washington, DC: World Bank.

World Bank. (2015b). The State of Social Safety Nets 2015. Washington, DC: World Bank.

World Bank (2016). Poverty and Shared Prosperity 2016: Taking on Inequality. Washington, DC: World Bank.

World Bank (2017). Closing the Gap: The State of Social Safety Nets 2017. Washington, DC: World Bank.

World Bank (2018). Povcalnet. http://iresearch.worldbank.org/PovcalNet/home.aspx 